\title{
FLOOD MAGNITUDE AND FREQUENCY OF JACKS RUN AT THE CULVERT ON U.S. ROUTE 206, SOUTHAMPTON TOWNSHIP, BURLINGTON COUNTY, NEW JERSEY
}

U.S. GEOLOGICAL SURVEY

Open-File Report 96-319

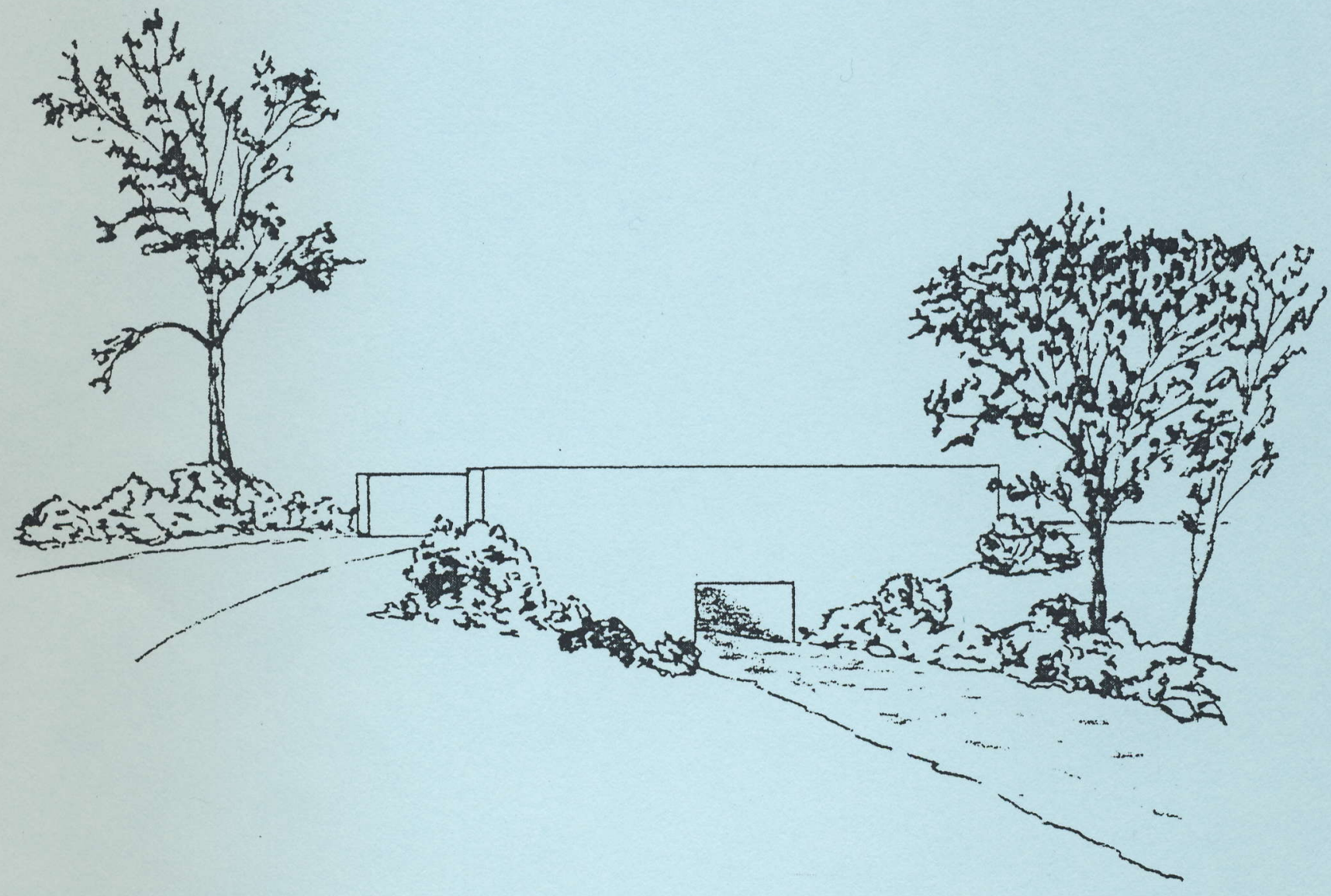

Prepared in cooperation with the NEW JERSEY DEPARTMENT OF TRANSPORTATION

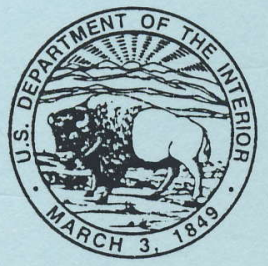


FLOOD MAGNITUDE AND FREQUENCY OF

JACKS RUN AT THE CULVERT ON U.S. ROUTE 206, SOUTHAMPTON TOWNSHIP, BURLINGTON COUNTY, NEW JERSEY

By Thomas Barringer

U.S. GEOLOGICAL SURVEY

Open-File Report 96-319

Prepared in cooperation with the

NEW JERSEY DEPARTMENT OF TRANSPORTATION

West Trenton, New Jersey 


\section{U.S. DEPARTMENT OF THE INTERIOR}

BRUCE BABBIT, Secretary

\section{U.S. GEOLOGICAL SURVEY}

Gordon P. Eaton, Director

For additional information write to:

District Chief

U.S Geological Survey Mountain View Office Park

810 Bear Tavern Road, Suite 206

West Trenton, NJ 08628
Copies of this report can be obtained from:

U.S Geological Survey

Earth Science Information Center

Open-File Reports Section

Box 25286, MS 517

Denver Federal Center

Denver, CO 80225 


\section{CONTENTS}

Page

Abstract....... 1

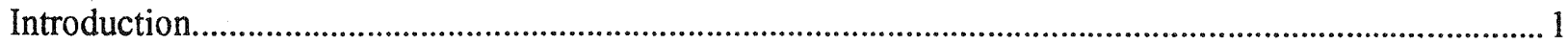

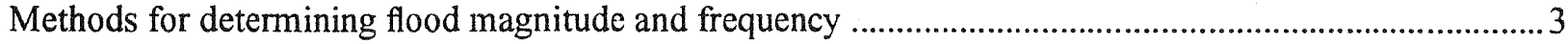

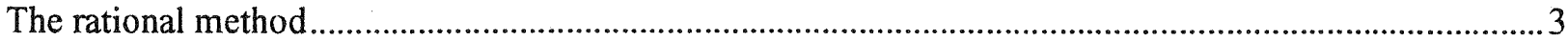

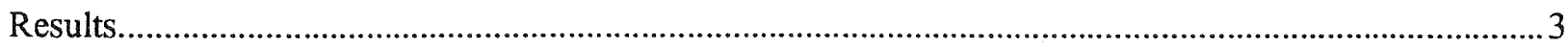

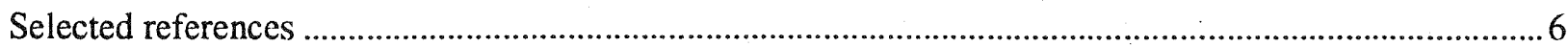

\section{ILLUSTRATIONS}

Figure 1. Map showing location of Jacks Run at the culvert on U.S. Route 206 and associated drainage basin, Southampton Township, New Jersey

\section{TABLES}

Table 1. Explanatory variables for the flood-magnitude and -frequency analysis of Jacks Run at the culvert on U.S. Route 206, Southampton Township, New Jersey

2. Estimates of flood magnitudes for selected flood frequencies using the rational method, Jacks Run, at the culvert on U.S. Route 206, Southampton Township, New Jersey ....................5 


\section{CONVERSION FACTORS}

Multiply

foot $(\mathrm{ft})$

mile (mi)

square mile $\left(\mathrm{mi}^{2}\right)$

foot per mile ( $\mathrm{ft} / \mathrm{mi}$ )

cubic foot per second $\left(\mathrm{ft}^{3} / \mathrm{s}\right)$
By

0.3048

1.609

2.590

0.189

0.0283
To obtain

meter

kilometer

square kilometer

meter per kilometer

cubic meter per second 


\title{
FLOOD MAGNITUDE AND FREQUENCY OF JACKS RUN AT THE CULVERT ON U.S. ROUTE 206, SOUTHAMPTON TOWNSHIP, BURLINGTON COUNTY, NEW JERSEY
}

\author{
By Thomas Barringer
}

\begin{abstract}
Flood magnitude and frequency of Jacks Run at the culvert on U.S. Route 206, Southampton Township, New Jersey, were determined by using the rational method. Flood magnitude and frequency estimates, as well as basin characteristics, are included in this report. The 100-year-flood estimate is 29 cubic feet per second.
\end{abstract}

\section{INTRODUCTION}

Information on the magnitude and frequency of floods is critical to the planning and design of highway culverts and bridges. This information is not readily available for many stream crossings in New Jersey. To fulfill this information need, the U.S. Geological Survey, in cooperation with the New Jersey Department of Transportation, began an analysis of flood data from stream-crossing sites on New Jersey streams.

This report presents results of the analysis for Jacks Run at the culvert on U.S. Route 206, Southampton Township, Burlington County, New Jersey. The culvert is located about 3,200 ft north of the Red Lion traffic circle in Southampton Township, New Jersey (fig. 1). The drainage area upstream from the site is $0.057 \mathrm{mi}^{2}$. A field reconnaissance was performed on March 22, 1995, to verify the locations of the drainage-basin divides and basin characteristics. Because the basin is mostly wooded and of low relief, the estimated drainage area is approximate.

The site reconnaisance revealed that the stream channel ends about 100 yards downstream from the subject culvert. In addition, a corrugated-plastic culvert had been installed under a county road about 200 yards downstream from the subject culvert. Nearby residents indicated that this culvert backs up during storms. The outflow from a detention basin empties into the blocked stream channel immediately downstream from the subject culvert; the stream channel is heavily overgrown with vegetation between the outflow and the end of the channel. The flooding at this site appears to be primarily the result of a lack of a continuous stream channel downstream of the culvert.

The Federal Emergency Management flood study for Southampton Township, Burlington County (Federal Emergency Management Agency, 1979), does not include a study of Jacks Run tributary to Beaverdam Creek. Hence, no discharge estimates are available for the subject site. 

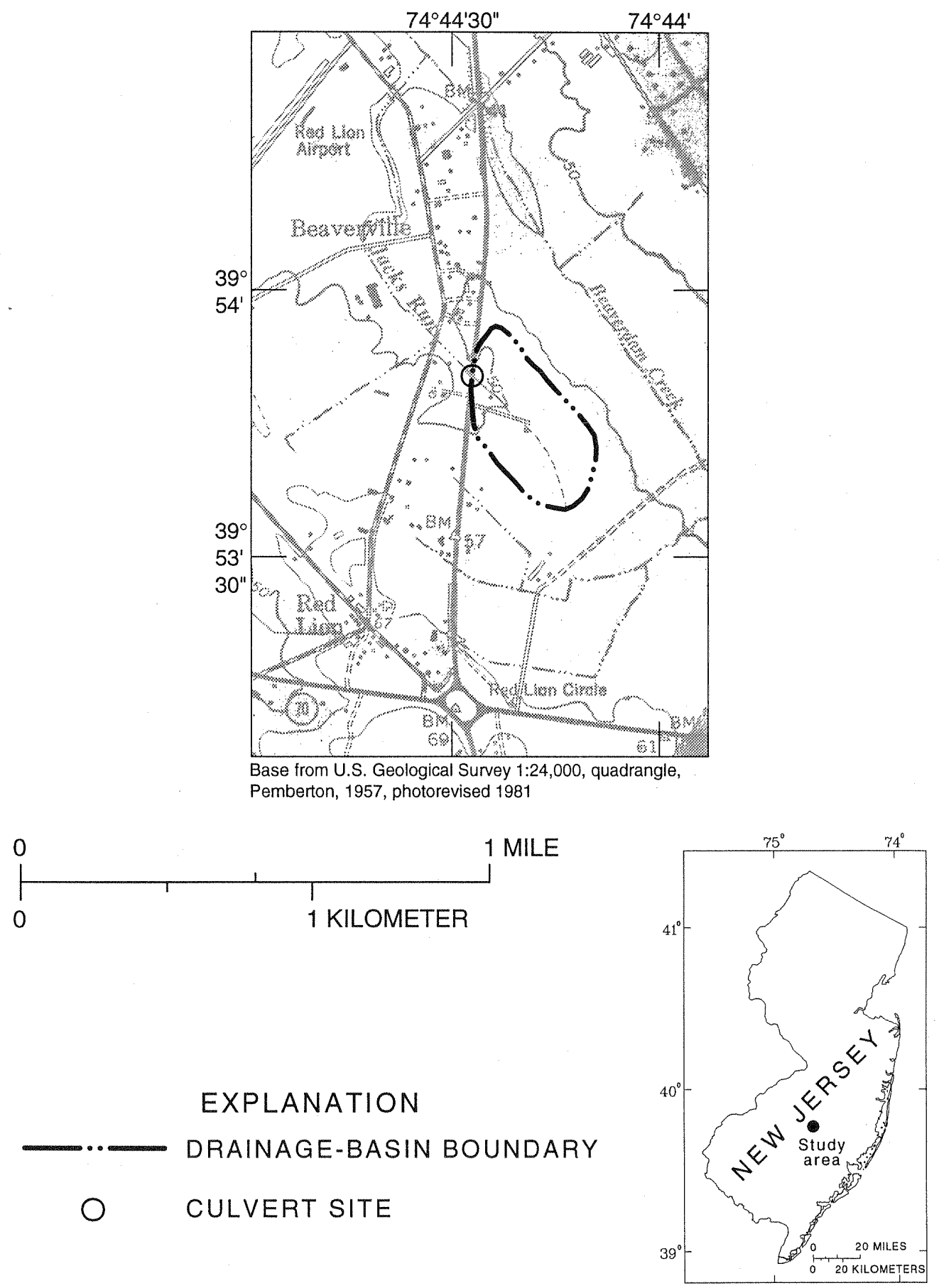

Figure 1. Location of Jacks Run at the culvert on U.S. Route 206 and associated drainage basin, Southhampton Township, New Jersey. 


\section{METHODS FOR DETERMINING FLOOD MAGNITUDE AND FREQUENCY}

Various widely used methods for calculating flood magnitude and frequency were given consideration in determining the flood magnitudes that are likely to be exceeded at this site within a given number of years (recurrence interval). The rational method (Chow and others, 1988), the New Jersey Department of Environmental Protection (NJDEP) Special Report 38 method (Stankowski, 1974), the U.S. Soil Conservation Service (SCS) Technical Release 55 (TR-55) method (U.S. Soil Conservation Service, 1986), the U.S. Geological Survey (USGS) transfer method (New Jersey Department of Environmental Protection, 1988), and the index-flood method (Thomas, 1964) were all given consideration in determining flood magnitude and frequency at the subject culvert.

\section{THE RATIONAL METHOD}

The rational method is recommended for determining peak flows for homogeneous drainage basins that are not more than $0.5 \mathrm{mi}^{2}$ in area. The subject basin has these characteristics. This method is probably the method most widely used in conjunction with storm-sewer design and is appealing for its simplicity (Chow and others, 1988).

\section{RESULTS}

Site reconnaisance revealed the presence of various conditions downstream from the subject culvert that could significantly influence flood magnitude at the site. The flood magnitude and frequency estimates presented in this report assume the existence of a free flowing stream channel downstream of the culvert.

Variables used in computing the rational method flood-magnitude and -frequency estimates are listed in table 1. The flood-magnitude and -frequency estimates made by using the rational method are shown in table 2. The estimate of the 100-year flood discharge at the culvert site is $29 \mathrm{ft}^{3} / \mathrm{s}$. 
Table 1. Explanatory variables for the flood-magnitude and -frequency analysis of Jacks Run at the culvert on U.S. Route 206, Southampton Township, New Jersey

Drainage area: 0.057 square miles

Latitude: $39^{\circ} 53^{\prime} 50^{\prime \prime}$

Longitude: $74^{\circ} 44^{\prime} 28^{\prime \prime}$

Highway: U.S. Route 206

Milepost: 18.4

U.S. Geological Survey 7-1/2-minute quadrangle: Pemberton, N.J.

\begin{tabular}{lll}
\hline \multicolumn{1}{c}{ Variable } & Value & Unit \\
\hline Drainage area & $=0.057$ & square miles \\
Rational method runoff coefficient & $=0.40$ & \\
2-year, 24-hour rainfall intensity ${ }^{1}$ & $=0.89$ & inches per hour \\
5-year, 24-hour rainfall intensity & $=1.15$ & inches per hour \\
10-year, 24-hour rainfall intensity & $=1.33$ & inches per hour \\
25-year, 24-hour rainfall intensity & $=1.54$ & inches per hour \\
50 -year, 24-hour rainfall intensity & $=1.73$ & inches per hour \\
100-year, 24-hour rainfall intensity & $=1.96$ & inches per hour \\
\hline
\end{tabular}

${ }^{1}$ From New Jersey Department of Environmental Protection, 1988.

${ }^{2}$ All rainfall intensity values from Frederick and others, 1977. 
Table 2. Estimates of flood magnitudes for selected flood frequencies using the rational method, Jacks Run at the culvert on U.S. Route 206, Southampton Township, New Jersey

[Q, flood-magnitude estimates in cubic feet per second along with number indicating frequency of the recurrence interval, in years]

Drainage area: 0.057 square miles

Latitude: $39^{\circ} 53^{\prime} 50^{\prime \prime}$

Longitude: $74^{\circ} 44^{\prime} 28^{\prime \prime}$

Highway: U.S. Route 206

Milepost: 18.4

U.S. Geological Survey 7-1/2-minute quadrangle: Pemberton, N.J.

\begin{tabular}{lcccccc}
\hline Estimating method & Q2 & Q5 & Q10 & Q25 & Q50 & Q100 \\
\hline Rational method & 13 & 17 & 19 & 23 & 25 & 29 \\
\hline
\end{tabular}




\section{SELECTED REFERENCES}

Chow, V.T., Maidment, D.R., and Mays, L.W., 1988, Applied hydrology: New York, McGraw-Hill, 572 p.

Federal Emergency Management Agency, 1979, Flood insurance study of Southampton Township, Burlington County, New Jersey: Federal Emergency Management Agency, September 1979, 29 p., 15 pls.

Frederick, R.H., Myers, V.A., and Auciello, E.P., 1977, Five- to 60-minute precipitation frequency for the eastern and central United States: National Oceanic and Atmospheric Administration Technical Memorandum NWS HYDRO-35, Silver Spring, Md., June 1977, 36 p.

New Jersey Department of Environmental Protection, 1988, Technical manual for stream encroachment: New Jersey Department of Environmental Protection, Division of Water Resources, Bureau of Floodplain Management, 151 p., 6 app.

Stankowski, S.J., 1974, Magnitude and frequency of floods in New Jersey with effects of urbanization: New Jersey Department of Environmental Protection, Special Report 38, 46 p.

Thomas, D.M., 1964, Floods in New Jersey, magnitude and frequency: New Jersey Department of Conservation and Economic Development, Water Resources Circular 13, 145 p.

U.S. Soil Conservation Service, 1986, Urban hydrology for small watersheds: Engineering Division Technical Release 55, Washington, D.C., 162 p. 